\title{
Structural bases of myocardial hypertrophy
}

\author{
Hubert Meessen \\ From The Institute of Pathology, University of Düsseldorf, Germany
}

Hypertrophy is undoubtedly the most important problem in the structural adaptation of heart muscle. It stands at the centre of medical discussion because it is just the hypertrophic heart muscle that, after performing efficiently for a long time, finally fails. For this reason structural researches into hypertrophy include those of myocardial failure (Büchner, 1950, 196I).

According to the macroscopical findings we speak of left-sided hypertrophy if mainly the left ventricle and the septum belonging to it increase in size, or of right-sided hypertrophy if the burden falls almost exclusively on the right ventricle. There are also forms, however, in which the hypertrophy involves the whole myocardium - for example, in cases of macrosplanchnia in acromegaly or in idiopathic cardiomegaly. From the macroscopical findings we can distinguish concentric hypertrophy with normal or even reduced lumen of the chamber. Concentric hypertrophy is especially found in hypertrophy due to raised pressure - for example, as a consequence of aortic stenosis, hypertension, etc. Eccentric hypertrophy, on the other hand, is found in the cardiac hypertrophy of athletes and in volume hypertrophy - for example, as a result of a shunt or a chronic lack of oxygen. In concentric hypertrophy with good cardiac efficiency the sarcomeres of the heart muscle contract extremely in systole, starting from a mean intensity in diastole; in eccentric hypertrophy, on the other hand, the diastolic active dilatation is greatest and the contraction only average in systole (Fig. I). Even if the heart volume is not increased, heart failure may be present in concentric hypertrophy and may be absent in spite of large heart volumes in eccentric volume hypertrophy (Reindell, Keul, and Doll, I968). Teare (1968) divides idiopathic hypertrophic subaortic stenosis into an asymmetrical form, which chiefly involves the region of the ventricular septum and anterior wall of the left ventricle, and a diffuse form. From our investigations (Meessen and Poche, 1967) with the electron microscope, however, even in parts of the asym- metrically formed heart which to the naked eye are not hypertrophied, growth process can be seen. We may therefore assume that both Teare's forms are only the expression of an often focal accentuated growth. A limit of the extent of hypertrophy is reached when the whole heart weighs often $500 \mathrm{~g}$., and sometimes $1000 \mathrm{~g}$. or more, instead of the normal $300 \mathrm{~g}$. In the extreme weights, however, not only the muscle mass but also the connective tissue is considerably increased. In Io cases of cardiac hypertrophy with AV block and a mean heart weight of $600 \mathrm{~g}$. the proportion of connective tissue amounted to 22 per cent (Knieriem and Effert, 1966). Linzbach (1950, 1960) set the 'critical weight of the heart' for the isolated left chamber at 200 to $250 \mathrm{~g}$. and for the whole heart at $500 \mathrm{~g}$., while Schoenmackers (1963) thought the upper limit of weight for the heart muscle to be $550 \mathrm{~g}$.

\section{Thickness of myocardial fibres}

The increase in the mass of the heart muscle is caused by the fact that the individual cells of the myocardium grow - that is, they become thicker and longer. The thickness of the myocardial fibres in the left ventricle in man, depending on the fixation, embedding, and

FIG. I Length of sarcomeres.
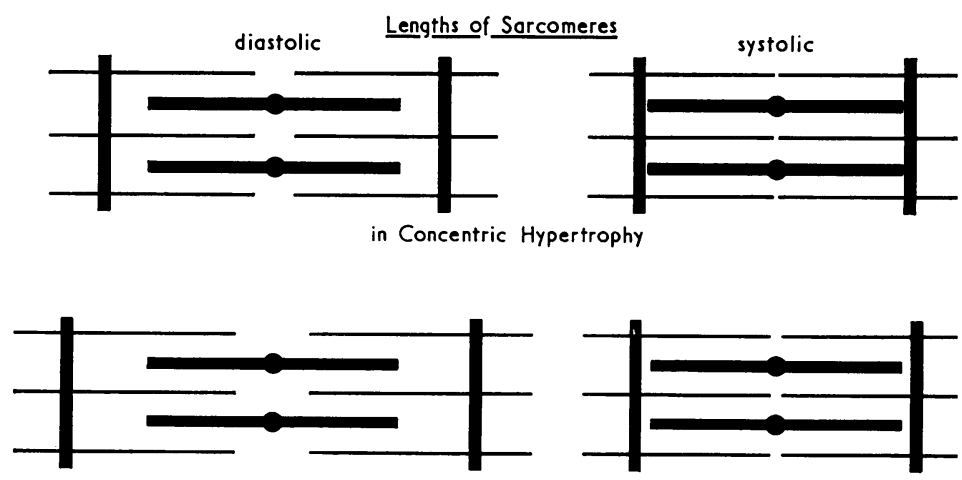

in Eccentric Hypertrophy 
the point of measurement, is on the average Io to $15 \mu \mathrm{m}$. In spite of the considerable differences in body weight, heart weight, and pulse rate, the differences in the thickness of the fibres in our experimental animals are relatively small compared with those found in in man, even in a whale with a heart weight of II $6 \mathrm{~kg}$. (Meessen and Poche, I963). In each species, however, the thickness of the fibres increases in strict relationship to the increasing heart weight. In left ventricular hypertrophy in man we can find fibres from 25 to $50 \mu \mathrm{m}$. thick. After repeated swimming periods of five hours a day, the muscle fibres in rats were significantly thickened after nine days in comparison with controls. After thirty days of swimming sessions the thickness was 17 instead of the normal $12 \mu \mathrm{m}$. (Bózner and Meessen, 1969). Pressure hypertrophy after induced aortic stenosis or after nephrogenic hypertension led to thickening of the fibres faster than training (Wollenberger and Schulze, 196r; Poche et al., 1968; Novi, 1968). In man, myocardial hypertrophy can be positively identified two to three weeks after the beginning of renal hypertension. In addition to the thickened, often deeply indented fibres, other fibres are always seen which are not yet thickened. The growth process gradually involves the individual fibres without ever changing them all. With a fibre thickness of $50 \mu \mathrm{m}$. in cases of idiopathic cardiac hypertrophy or acromegaly the 'critical cell size' may be attained or exceeded. The exchange of materials between the individual cell compartments is made more difficult and the supply of oxygen from the oxygen pressure areas surrounding the capillaries is no longer possible in sufficient amounts. Examination with the electron microscope enables the recognition of irregular heaps of mitochondria or glycogen and irregular ramifications and contractions as signs of distorted arrangement of the structure of hypertrophied cells in cases of idiopathic myocardiopathy (Meessen and Poche, 1967).

\section{Quality of the nuclei}

Increases in the volume of the nuclei have long been known in cardiac hypertrophy in man. With more prolonged myocardial strain the stage of functional nuclear oedema is passed and duplication of the DNA content of the nucleus appears. My co-worker Pfitzer (1970) has systematically examined the process of the increase of DNA content in isolated nuclei from normal and hypertrophied human hearts. In a 4-day-old infant most of the myocardial nuclei are diploid. Between the fifth and tenth day of life, depending on the growth and increase in the weight of the heart, a shift in favour of the tetraploid form occurs, along with a few octaploid forms of the cell nuclei. This distribution pattern can be maintained with slight deviations up to senescence. In myocardial hypertrophy following hypertension, as well as in hypertrophy in cases of acromegaly, the quality of the nuclei shifts towards the polyploid forms. The change in the quality of the nuclei was seen clearly in the heart of a 24-year-old man with idiopathic hypertrophic myocardiopathy and a heart weight of $1054 \mathrm{~g}$. In this case we found, in addition to 2,4 , and 8-ploid nuclei, 16,32 , and 64-ploid cell nuclei (Fig. 2). Corresponding changes were seen in hypertrophy of the right ventricle. In congenital cardiac and vascular disorders the shift towards the higher degrees of ploidy, which normally appears between the fifth and tenth year of life, can be seen to have occurred at birth in strained heart sections.

In contrast to the findings in man, Pfitzer and Kuhn (1970) found in rats with renal hypertension that after nine weeks, and also after three and nine months, there was no increase in the DNA content of the myocardial nuclei. The quality of the nucleus had also not changed, though the cardiac hypertrophy, measured by heart weight and the average thickness of the fibres, was significant. Slight enlargements of the nuclear surface or volume after running or swimming training are only the manifestation of a reversible nuclear oedema (Ross, 1967). The nuclear protein

FIG. 2 2, 4, 8, 16, 32, and 64-ploid nuclei.

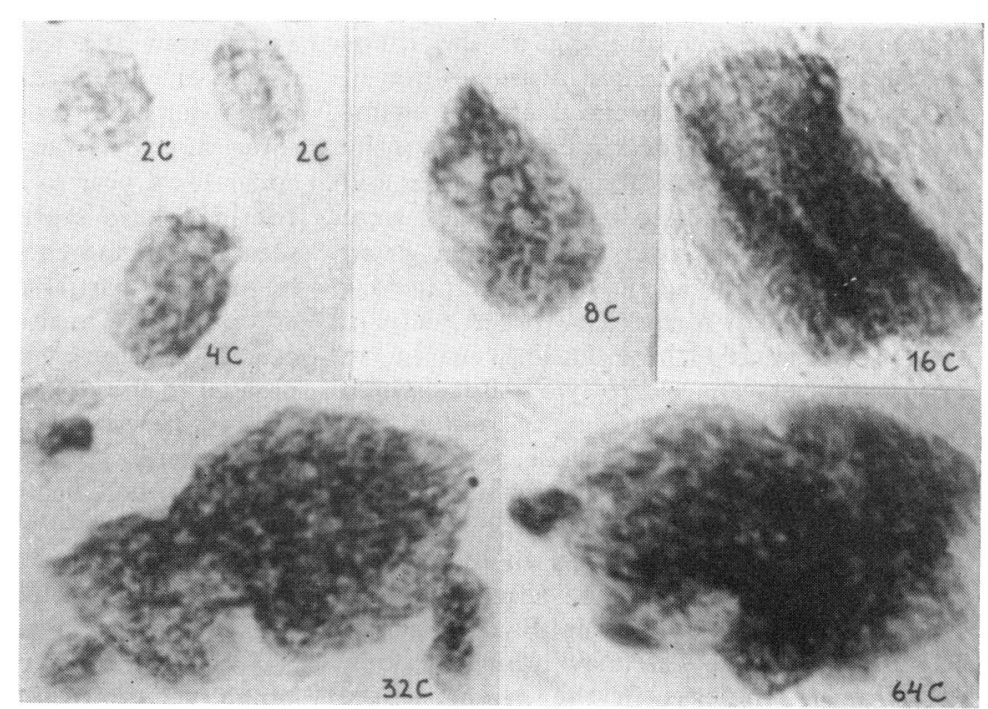


did not increase according to our histoautoradiographic examinations with $\mathrm{H}-3-\mathrm{DL}-\mathrm{leu}-$ cine in the hypertrophied rat heart, but relatively decreased (Breithardt, Hilscher, and Poche, 1969). These differences of reaction in hypertrophy between man and the usual experimental animals have not been sufficiently considered hitherto.

In healthy and in hypertrophied human hearts isolated duplicated nuclei and, very seldom, occasionally a mitosis appear. Pfitzer and Capurso (1970) have checked and confirmed these findings in 202 auricular appendages obtained at operations for mitral stenosis. In young growing rats and mice an increase in the DNA content of the muscular nuclei and isolated mitoses are found in hypertrophy (Wegner and Mölbert, 1966; Citoler and Kunze, 1967). The tendency to proliferation in the myocardial cells is, however, only seen in adolescent animals. From all the information available today it cannot be concluded that either in man or in the usual experimental animals, after the end of the growth phase of the body, a worth-while number of hyperplasic processes play a part in the increase of the myocardial mass. The smooth muscle cells and the endothelial cells of the cardiac vessels and the fibroblasts of the interstices, on the other hand, increase in hypertrophy at any age through mitosis (Meessen, 1970). Further work on the differentiation between hyperplasia and hypertrophy is necessary.

\section{Swelling of mitochondria}

After swimming for as little as two hours a slight adaptation swelling of the mitochondria can be seen with the help of the electron microscope. Greater swelling of the mitochondria and circumscribed disintegration of the myofibrils were observed after a swimming period which ended in exhaustion of the animals after 13 hours (Fig. 3) (Bózner and Meessen, 1969). These early changes were even more obvious after compression strain in experimental aortic and pulmonary stenosis. With my former co-worker Poche in 196I I considered these findings to be an expression of an electrolyte shift which resulted in the absorption of water and nutrients. This process can be so intensive that thickening of the fibres and an increase in the volume of the nuclei may be seen with a light microscope, and even an increase in heart weight occurs. As the second step in hypertrophy, my co-worker Bózner and I saw in rats, after repeated swimming sessions, a significant increase in the extent of the

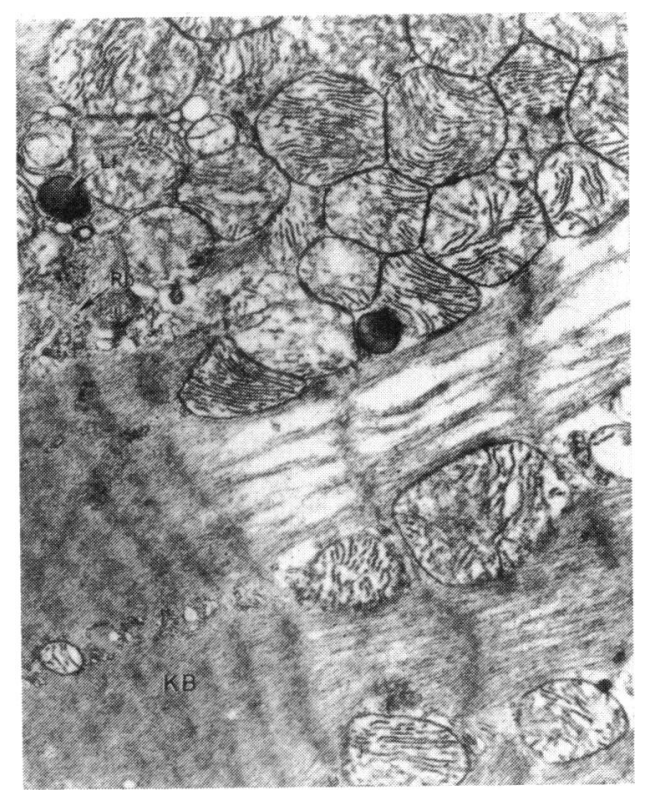

FIG. 3 Swelling of mitochondria and disintegration of myofilaments after 13 hours of swimming training.

mitochondria. The shift in the direction of the mitochondria in the mitochondria/myofibril ratio persists until the 40th day of the swimming sessions. The increase in the number and extent of the mitochondria is not specific for hypertrophy; however, we could also produce this adjustment, obviously prepared in the cell, in rats through thiamine deprivation (Bózner et al., 1969). As we were able to show, in agreement with Novi (1968), in pressure hypertrophy the proportion of mitochondria to myofibrils finally shifted away from the mitochondria after a brief period of equilibrium. In rats with renal hypertension the ratio fell significantly after three months from the normal 0.67 to 0.3 , and after a year to 0.23 (Poche et al., 1968). In this phase regressive changes are to be seen in the mitochondria (Fig. 4 and 5) and finally also partial disintegration or necrosis and atrophy (Onishi et al., 1969). Often signs of cardiac failure are to be seen then. Almost parallel to the dynamics of the morphological changes in the mitochondria runs the increase in ribosomes and polysomes which is detectable morphologically in the strained heart muscle after only a few hours. In the myocardial cells ergastoplasmic membranes are then to be seen, which almost never occurs in the fully grown heart of the rat.

According to our investigations, the third phase of hypertrophy, the formation of myo- 
filaments, sets in somewhat later - seven to eleven days after the beginning of the swimming training. Also, during the permanent strain of a pressure hypertrophy due to aortic stenosis the formation of new myofilaments is scarcely seen before the fifth day. The myofilaments lying in the sarcoplasm are arranged below the sarcolemma and transformed into myofibrils and sarcomeres capable of functioning (Fig. 6); the fibres become thicker and contain more myofibrils. Longitudinal growth occurs stage by stage at the stepwise dovetailing of the intercalary discs. The new contraction units do not differ from the old ones; they are surrounded by a network of tubules of the sarcoplasmic reticulum and rarely exceed the normal thickness of $\mathrm{I} \mu \mathrm{m}$. (Richter and Kellner, 1963). However, in cases of idiopathic myocardial hypertrophy in man we saw fibrils up to $3 \mu \mathrm{m}$. thick. Of the remaining findings which came to light under the electron microscope we must mention that the myocardial cells in all forms of hypertrophy had a very enlarged and indented surface, and the transverse and longitudinal tubules filled with adenosine triphosphatase are distended (Fig. 7). Under the sarcolemma numerous pinocytotic vesicles are to be seen; the glycogen content, as well as the myoglobin (Blessing, 1967, 1970) may be increased. Increased myocardial performance may be brought about for example, after easy training - by the fact

FIG. 4 Experimental hypertrophy in aortic stenosis (after 260 days). Formation of tubules (arrowed) in mitochondria.

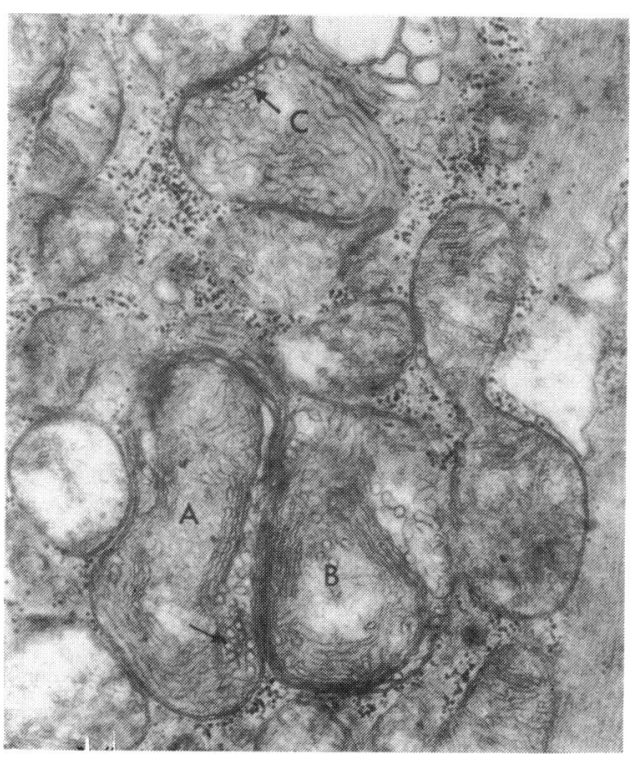

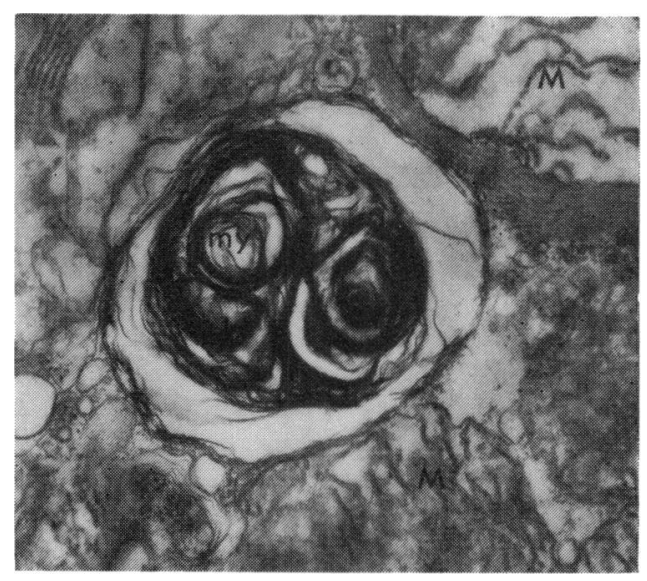

FIG. 5 Experimental hypertrophy in aortic stenosis (after 360 days). Myelin structures $(m y)$ and swelling of mitochondria $(M)$.

that in the active contraction and active dilatation the activity of all the contractile filaments in the individual myocardial cells, even all the cells of the myocardium, is better synchronized (Meessen and Poche, 1963; Bloor and Leon, 1970). After more strenuous training oedema of the cells and nuclei occurs, followed very rapidly by an increase in the

FIG. 6 Idiopathic hypertrophy. Threadlike formation of new myofilaments (arrowed).

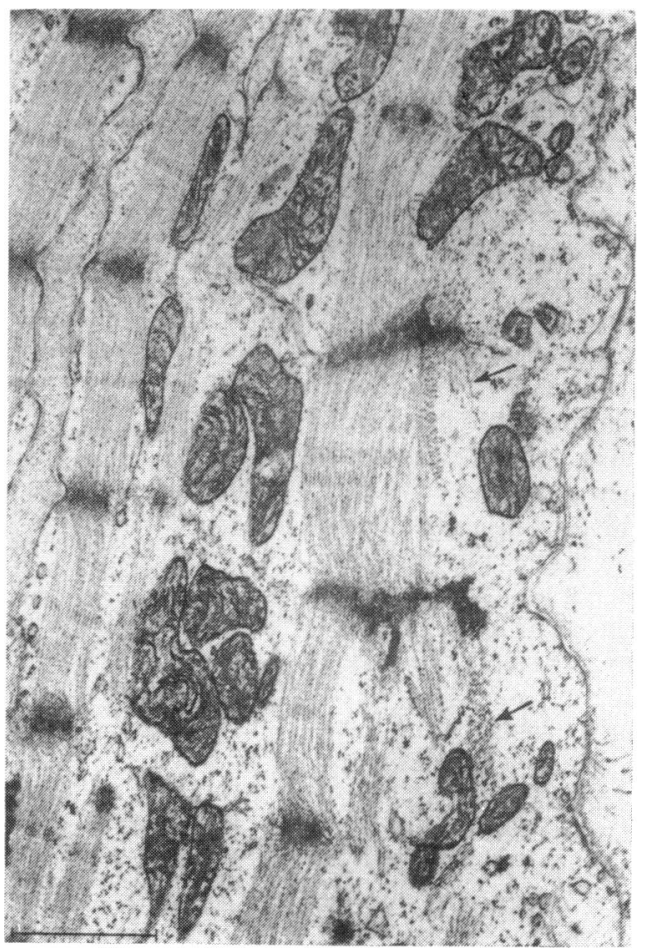


amount of mitochondria, thus providing improved supply of the products rich in energy. Full adaptation in the sense of hypertrophy is, however, achieved only if the protein synthesis controlled by the RNA content permits an increase in the number of contractile units in the cells. In man the increase in the volume of cell plasma is accompanied by an increase in the DNA content of the nucleus. Adult experimental animals do not achieve this form of adaptation.

Hypertrophic heart failure is characterized by disturbances of the structural flow balance (Meessen, 1967, 1968). In the submicroscopical range electrolyte shifts are in the foreground in acute overstrain oedema of the cells and nuclei; it can very quickly develop into a circumscribed disintegration in the cells and into cell necrosis. In chronic strain the ratio between the number and extent of mitochondria and the number of contractile units becomes unfavourable over a period of time. Regressive changes in the mitochondria advance the processand lead to atrophy and necrosis and finally to interstitial fibrosis. The increase in DNA content of the nucleus seen in man is distorted by high degrees of polyploidy. The DNA and protein synthesis is finally dependent on age and nutrition and is affected, for example, by

growth hormone and by the nervous system (Barta et al., 1967a, b). The ratio of fibres to capillaries becomes more and more unfavourable through the increase in the volume of individual muscle fibres. Disturbances of the microcirculation may irreversibly damage the metabolism of the cells (Poche, Arnold, and Nier, 1969; Poche, 1969). Finally the growth of the ostia and the main branches of the coronary arteries no longer follows the hypertrophy of the myocardium in spite of the hyperplasia of the smooth muscle cells of the vessels (Schoenmackers, 1963). The increase in the bulk of the myocardium, the hypertrophy, is then limited by cellular disturbances of metabolism.

\section{References}

Barta, E., Fízel'ová, A., Breuer, E., and Fízel, A. (I967a). Participation of the nervous system in the control of protein and nucleic acid metabolism in the heart muscle. Cor et Vasa, 9, 282.

, Sapáková, E., and Zlatoš, L. (1967b). Changes in adrenal activity in the course of experimental compensatory hyperfunction of the heart. Cor et Vasa, 9, 163.

Blessing, M. H. (1967). Uber den Myoglobingehalt des Herzmuskels des Menschen. Archiv für Kreislaufforschung, 52, 236.

(1970). Myoglobingehalt des Herzmuskels bei Morbus caeruleus. Verhandlungen der Deutschen Gesellschaft für Pathologie. In press.

Bloor, C. M., and Leon, A. S. (I970). Interaction of age and exercise on the heart and its blood supply. Laboratory Investigation, 22, 160.

Bózner, A., Knieriem, H. J., Meessen, H., and Reinauer, H. (1969). Die Ultrastruktur und Biochemie des Herzmuskels der Ratte im Thiaminmangel und nach einer Gabe von Thiamin. Virchows Archiv Abteilung B. Zellpathologie, 2, 125 .

, and Meessen, H. (1969). Die Feinstruktur des Herzmuskels der Ratte nach einmaligem und nach wiederholtem Schwimmtraining. Virchows Archiv Abteilung B. Zellpathologie, 3, 248.

Breithardt, G., Hilscher, W., and Poche, R. (1969). Autohistoradiographische Untersuchungen über den Einbau von H-3-Leucin in den hypertrophierten Herzmuskel nach Schwimmtraining. Archiv für Kreislaufforschung, 59, $35 \mathrm{I}$.

Büchner, F. (1950). Pathologische Anatomie der Herzinsuffizienz. Verhandlungen der Deutschen Gesellschaft für Kreislaufforschung, 16, 26.

(I96I). Die Pathologie des Herzmuskelstoffwechsels vom Standpunkt der elektronenmikroskopischen Morphologie. Verhandlungen der Deutschen Gesellschaft für Kreislaufforschung, 27, 125.

Citoler, P., and Kunze, W. P. (1967). Autoradiographische Untersuchung über Proliferation von Herzmuskelzellen. Verhandlungen der Deutschen Gesellschaft für Pathologie, 51, 166.

Knieriem, H. J., and Effert, S. (I966). Morphologische Befunde bei komplettem Herzblock. Klinische Wochenschrift, 44, 349.

Linzbach, A. J. (1950). Die quantitative Anatomie des normalen und vergrosserten Herzens im Hinblick auf die Herzinsuffizienz. Verhandlungen der Deutschen Gesellschaft für Kreislaufforschung, 16, 43. 
-

- (1960). Heart failure from the point of view of quantitative anatomy. American fournal of Cardiology, 5, 370.

Meessen, H. (1967). Morphologische Grundlagen der akuten und der chronischen Myokardinsuffizienz. Verhandlungen der Deutschen Gesellschaft für Pathologie, 51, 3.

(1968). Ultrastructure of the myocardium. Its significance in myocardial disease. American fournal of Cardiology, 22, 319.

(1970). Contribution on the morphology of coronary sclerosis. Fortschritte der Kardiologie, 4, 3.

, and Poche, R. (1963). Pathomorphologie des Myokards. In Das Herz des Menschen, Vol. II, p. 644. Ed. by W. Bargmann and W. Doerr. Thieme, Stuttgart.

, and - (1967). Beiträge zur pathologischen Anatomie der Fallotschen Fehler und zur idiopathischen Herzhypertrophie. Anglo-German Medical Review, 4, 73.

Novi, A. M. (1968). Beitrag zur Feinstruktur des Herzmuskels bei experimenteller Herzhypertrophie. Beiträge zur pathologischen Anatomie und zur allgemeinen Pathologie, 137, 19.

Onishi, S., Büchner, F., Zittel, R., and Thermann, M. (1969). Das elektronenmikroskopische Bild der Herzmuskelzelle des Hundes bei experimenteller Herzhypertrophie in der Anpassungsphase. Beitrage zur pathologischen Anatomie und zur allgemeinen Pathologie, 139, 94.

Pfitzer, P. (1970). Der DNS-Gehalt der Zellkerne des Herzmuskels beim Menschen. Virchows Archiv $A b$ teilung B. Zellpathologie, 5, 254.

, and Capurso, A. (1970). Der DNS-Gehalt der Zellkerne im Herzohr des Menschen. Virchows Archiv Abteilung B. Zellpathologie, 5, 254.

, and Kuhn, H. (1970). DNS-Gehalt und DNSSynthese in den Zellkernen normaler und hypertrophierter Rattenherzen Verhandlungen der Deutschen Gesellschaft für Pathologie. In press.
Poche, R. (1969). Die kleinherdige hypoxydotische Herzmuskelnekrose. Deutsche medizinische Wochenschrift, 94, 1851 .

—, Arnold, G., and Nier, H. (1969). Die Ultrastruktur der Muskelzellen und der Blutcapillaren des isolierten Rattenherzens nach diffuser Ischämie und Hyperkapnie. Virchows Archiv Abteilung $A$. Pathologische Anatomie, 346, 239.

, de Mello Mattos, C. M., Rembarz, H. W., and Stoepel, K. (1968). Über das Verhältnis Mitochondrien: Myofibrillen in den Herzmuskelzellen der Ratte bei Druckhypertrophie des Herzens. Virchows Archiv Abteilung A. Pathologische Anatomie, 344, 100.

Reindell, H., Keul, J., and Doll, E. (1968). Heart Failure. Pathophysiological and Clinical Aspects. Thieme, Stuttgart.

Richter, G. W., and Kellner, A. (1963). Hypertrophy of the human heart at the level of fine structure. fournal of Cell Biology, 18, 195.

Ross, W. (1967). Karyometrische Untersuchungen am funktionell belasteten Herzmuskel der Ratte. Verhandlungen der Deutschen Gesellschaft für Pathologie, 5I, I6I.

Schoenmackers, J. (1963). Koronararterien, Herzinfarkt. In Das Herz des Menschen, Vol. II, p. 735. Ed. by W. Bargmann and W. Doerr. Thieme, Stuttgart.

Teare, D. (1958). Asymmetrical hypertrophy of the heart in young adults. British Heart fournal, 20, I.

Wegner, G., and Mölbert, E. (1966). Das Verhalten des Myokards bei der experimentellen supravalvulären Aortenstenose. Autoradiographische und

- elektronenmikroskopische Untersuchungen an Rattenherzen. Virchows Archiv für Pathologische Anatomie und Physiologie und für Klinische Medizin, 341, 54.

Wollenberger, A., and Schulze, W. (196I). Mitochondrial alterations in the myocardium of dogs with aortic stenosis. Fournal of Biophysical and Biochemical Cytology, 10, 285. 